\title{
A bill of rights for bioentrepreneurs
}

\section{With international growth being driven by bioentrepreneurs, nations must take action to protect this enterprise.}

\author{
Carl B. Feldbaum
}

The biotechnology industry's companies are among today's leaders in job creation, technological innovation, and international competitiveness. With our future economic well-being depending on these emerging companies, the central organizing principle for global economic policy should be bioentrepreneurship. The following nine points represent what we consider to be the bare necessities-a bioentrepreneur's bill of rights-for allowing this enterprise to flourish worldwide.

\section{Right to intellectual property protection \\ At both the national and international level, intellectual property creations of entrepreneurs and entrepreneurial firms must be fully and vigorously protected. Without patents, trademarks, and copyrights entrepreneurs cannot raise capital to fund research and cannot justify the expenditure of funds to research and develop new tech- nologies and products.}

\section{Right to education, employment and training}

Governments should support education, labor, and training policies that support scientific research and development. Succeeding in the information-age economy of the 21st century requires a finely tuned economy backed by a thriving and high-performing commercial sector. Our increasingly intelligent workplaces-and the machines that help us to run them-demand equally intelligent workers.

\section{Right to funding for basic research and technology transfer}

Governments should continue to fund basic scientific research and to ensure that this research is transferred to entrepreneurs and entrepreneurial firms on commercially rea-

Carl B. Feldbaum is president of the Biotechnology Industry Organization, 1625 K Street NW, Suite 1100, Washington, DC 20006 (cfeldbaum@bio.org).
Bioentrepreneurs epitomize the fundamental values of the rights of the individual, freedom of speech and choice, democracy and restraints on bureaucracy and concentrations of power, and private ownership of property. These values characterize governments that have provided the highest level of human rights and standard of living for their citizens.

sonable terms for development of products for the marketplace. Breakthroughs in basic research can provide the foundation for whole new industries, whole new technologies, and new occupations and jobs.

\section{Right to a modern, science-based regulatory system}

Governments should ensure that agencies reviewing biotechnology products be adequately funded and use up-to-date, sciencebased regulations to ensure that safe, effective new products reach patients and other consumers without unwarranted cost or delay. National regulatory regimes put in place years ago need to be modernized and gratuitous political hurdles eliminated in favor of strict, but science-based regulation that will encourage investment and allow bioentrepreneurs to bring safe new products to patients and the marketplace with all deliberate speed.

\section{Right to a fair tax structure and long-term incentives}

Governments should enact tax incentives for patient, long-term capital formation for entrepreneurs to fund research and development and to bring new technologies and products to market.

A tax system that favors entrepreneurial activity and business growth is essential for a nation's economic growth. One of the great- est economic problems facing many countries that have or are seeking to grow a biotechnology infrastructure is formation of risk capital.

\section{Right to legal protection}

Governments should limit the initiation of meritless shareholder suits against entrepreneurs and entrepreneurial firms.

The US Congress's Private Securities Litigation Reform Act of 1995 should serve as a model piece of legislation for how countries can protect and grow their bioentrepreneurial communities.

\section{Right to employ qualified} international employees

Governments should cooperate to protect the interests of bioentrepreneurs and bioentrepreneurial firms internationally.

Bioentrepreneurial firms should not be limited in the number of foreign workers they can hire to meet their needs. Limitations on the number of employment-based visas may result in the company being forced to locate its research facilities in nations where qualified workers are more plentiful, thus limiting the growth of the international bioentrepreneurial infrastructure.

\section{Right to fair financial market regulation}

Governments should ensure that securities regulatory agencies adopt financial market regulations that reduce the burden for entrepreneurs and entrepreneurial firms in private placements, initial public offerings, and secondary offerings of stock on the public markets.

\section{Right to representation}

Governments need to create high-level posts within their administrations to protect bioentrepreneurial activity.

Highly qualified people in these positions will help to ensure that entrepreneurs have access to senior policymakers and that the government's policies and actions are consistent with an agenda that promotes bioentrepreneurial activities. 